\title{
Effect of Acacia angustissima Leaf Meal on the Physiology of Broiler Intestines
}

\author{
Sharai Ncube ${ }^{1}$, Tinyiko E. Halimani ${ }^{1}$, Marizvikuru Mwale ${ }^{2} \&$ Petronella T. Saidi ${ }^{1}$ \\ ${ }^{1}$ University of Zimbabwe, Faculty of Agriculture, Department of Animal Science, Harare, Zimbabwe \\ ${ }^{2}$ Institute for Rural Development, University of Venda, Thohoyandou, South Africa \\ Correspondence: Sharai Ncube, University of Zimbabwe, Faculty of Agriculture, Department of Animal Science, \\ Box MP167, Mt Pleasant, Harare, Zimbabwe. Tel: 263-4-303211 Ext. 15511. E-mail: sharaincube7@gmail.com
}

Received: October 11, 2016

Accepted: November 26, 2016

Online Published: January 15, 2017

doi:10.5539/jas.v9n2p53

URL: http://dx.doi.org/10.5539/jas.v9n2p53

\begin{abstract}
The effect of $A$. angustissima leaf meal based diets on intestinal physiology and dressed carcass weight was investigated on 150 day old chicks. Three diets, 0,5 and $10 \%$ A. angustissima were used in a three phase feeding programme. At days 14, 28 and 42, two birds from each replicate were slaughtered, dressed and weighed. The weights and lengths of the duodenum, jejunum and colon were measured. Approximately $1 \mathrm{~cm}$ specimen was taken from each organ, fixed in formalin and stained for histological analysis. Using a light microscopy, the digestive and absorptive properties of the tissues were assessed. Inclusion of $A$. angustissima leaf meal increased intestinal wall thickness, epithelial thickness, and villus height of the duodenum $(P<0.05)$. There was no effect on the proportional weight and length of the jejunum, jejunum villi height and villi width $(P>0.05)$ but jejunum wall thickness decreased with increasing levels of the leaf meal $(P<0.05)$. Leaf meal inclusion resulted in an increase in weight, intestinal wall and mucosal thickness of the colon $(P<0.05)$ and a decline in sub-mucosal fold height and haustra coli width of the colon $(P<0.05)$. Dressed weight was the same across diets at two weeks $(P>0.05)$. At four and six weeks, broilers on the control and 5\% diet had superior dressed weights to the $10 \%$ fed broilers $(P$ $<0.05$ ). It was concluded that for intestinal physiological adaptation that will not compromise weight gain in broilers, up to $5 \%$ A. angustissima could be included in broiler diets.
\end{abstract}

Keywords: Acacia angustissima leaf meal, crude fiber, digestive, duodenum, jejenum, morphology

\section{Introduction}

Poultry production has a major role to play in the economy of developing countries (Shaikh \& Zala, 2011; Oladokun \& Jonhson, 2012; Sambo et al., 2015) but the cost of feed is thwarting production (Casartelli, Filardi, Junqueira, Laurentiz, \& Duarte, 2006; Moreki, 2011; Ja'afar-Furo \& Gabdo, 2010; Ntuli \& Oladele, 2013). Increasingly the deficit of traditional ingredients such as soyabean (Martens, Temann, Bendelle, Peters, \& Lascano, 2012; Mutayoba, Dierenfed, Mercedes, Frances, \& Knight, 2011), increasing trends of severe droughts (Sheffield \& Wood, 2010) and competition for feed resources between humans and chickens (Ncube, Hamudikuwanda, \& Banda, 2012a) continue to be blamed for high cost of poultry feeds. This has come to the attention of scientist, thus the search for alternative protein poultry ingredients and especially those from drought tolerant plants also not attracting competition between people and animals.

Among the ingredients of interest is leaf meal from Acacia angustissima, a tropical legume multiple-purpose tree of the Mimosaceae family (Dzowela, 1994). The tree is adaptable to drought conditions (Dzowela, 1994) and produces up to $12.4 \mathrm{t} \mathrm{Ha}^{-1}$ of biomass (Preece \& Brook, 1999). A number of scientists have reported reasonable crude protein levels from the leaf meal ranging from 19\%-26.5\% (Rubanza, Shem, Bakengesa, Ichinohe, \& Fujihara, 2007; Odenyo et al., 2003; McSweeney et al., 2005; Mukandiwa, Mugabe, Halimani, \& Hamudikuwanda, 2010; Ncube et al., 2012a; Gusha, Ngongoni, \& Halimani, 2013), indicative of its potential use as a protein source. Its potential in broiler diets has already been established (Ncube et al., 2012a; Ncube, Hamudikuwanda, \& Saidi, 2012b; Ncube, Saidi, \& Halimani, 2015) but research supporting its use in broiler diets is still at its infancy. Most of the information available relate to its chemical composition (Reed et al., 2001; Odenyo et al., 2003; McSweeney et al., 2005; Mukandiwa et al., 2010; Gusha et al., 2013), appropriateness of processing techniques and harvesting stage for broiler feeding (Ncube et al., 2015) and effect on growth performance (Ncube et al., 2012a, 2012b). 
Not much has been established regarding its effect on the physiology of gastrointestinal organs. Ncube et al. (2012b) noted a gross increase in the proportional weight of the intestines with increasing levels of the leaf meal. However the study did not go further to check the actual physiological changes causing intestinal weight increases. Such investigations are important because the gastrointestinal tract is the primary surface of contact with digesta (Koutsos \& Arias, 2006). Its physiological state will determine the digestive and absorptive capacity of the intestine, and consequently growth performance of broilers (Roberts et al., 2005; Haoyu, Ivarsson, Lundh, \& Lindberg, 2013). Thus, it is important to investigate the effect of the leaf meal on the digestive and absorptive properties of intestines. Such information would be helpful in determining inclusion levels that support the development of the gastrointestinal tract without interfering with live weight gain. It was the objective of this study therefore to assess the physiological adaptation of the broiler intestines to increasing levels of $A$. Angustissima leaf meal and how these may influence carcass weight. The study hypothesized that broiler intestines are able to adjust to increasing levels of $A$. angustissima leaf meal in their diets without a compromise on carcass weights.

\section{Materials and Method}

Acacia angustissima leaves were harvested at mid-maturity, air dried (Ncube et al., 2015) and ground through a 1 mm sieve. Dry matter, crude protein, crude fiber and ash were determined using AOAC (1990) methods and condensed tannins were determined using the Butanol-HCL method (Porter, Hrstich, \& Chan, 1986) (Table 1). Three iso-nitrogenous and iso-energetic diets were formulated for a three phase feeding programme at $0 \%, 5 \%$ and $10 \%$ leaf meal inclusion (Table 2). Formulation was done using Spesfeed Express Formulation programme from Capital Foods, Harare, Zimbabwe, targeting, the National Research Council recommended nutrient levels for broilers (NRC, 1994). The diets were analysed for dry matter, crude protein, crude fiber, crude ash, $\mathrm{P}$ and $\mathrm{Ca}$ (AOAC, 1990), condensed tannins (Porter et al., 1986).

A total of 150 day old unsexed Cobb 500 chicks with an average weight of $41.7 \pm 1.560 \mathrm{~g}$, were randomly allocated to 15 cages of $1 \mathrm{~m}$ width $\times 1 \mathrm{~m}$ length, with 10 birds per cage. The cages were randomly allocated to the three diets, replicated five times in a completely randomized design. The cages were located in a temperature controlled room. The starter, grower and finisher diets were fed from week 1 to 2 , week 3 to 4 and week 5 to 6 , respectively. Feed and water were provided ad libitum throughout the trial. All other growing conditions were constant across treatments. All procedures in this experiment followed guidelines by the Zimbabwe Scientific Animal Act, 1963, subsection 2 of section 4, License Number L624.

Table 1. Chemical composition of Acacia angustissima leaf meal

\begin{tabular}{ll}
\hline Chemical component & Percentage (\%) \\
\hline Dry matter & 90.00 \\
Crude Ash & 4.77 \\
Crude protein & 23.40 \\
Crude fibre & 13.00 \\
Calcium & 0.94 \\
Phosphorus & 0.17 \\
Condensed tannins & 1.06 \\
\hline
\end{tabular}


Table 2. Ingredient and chemical composition of the diets

\begin{tabular}{|c|c|c|c|c|c|c|c|c|c|}
\hline \multirow{2}{*}{ Ingredient(kg) } & \multicolumn{3}{|c|}{ Starter Diets } & \multicolumn{3}{|c|}{ Grower Diets } & \multicolumn{3}{|c|}{ Finisher Diets } \\
\hline & Control & Diet 1 & Diet 2 & Control & Diet 1 & Diet 2 & Control & Diet 1 & Diet 2 \\
\hline Soya Meal, $46 \%$ CP & 30.00 & 25.00 & 20.00 & 18.7 & 13.70 & 8.70 & 18.60 & 13.60 & 8.60 \\
\hline Meat and Bone Meal, $45 \% \mathrm{CP}$ & 5.00 & 5.00 & 5.00 & 5.00 & 5.00 & 5.00 & 5.00 & 5.00 & 5.00 \\
\hline Sorghum meal, $9 \% \mathrm{CP}$ & 10.00 & 0.00 & 10.00 & 0.00 & 9.90 & 10.00 & 0.00 & 0.00 & 0.00 \\
\hline Acacia leaf meal, $23 \% \mathrm{CP}$ & 0.00 & 5.00 & 10.00 & 0.00 & 5.00 & 10.00 & 0.00 & 5.00 & 10.00 \\
\hline Blood meal $80 \% \mathrm{CP}$ & 0.00 & 0.00 & 0.00 & 0.00 & 2.00 & 3.00 & 1.20 & 1.80 & 3.00 \\
\hline Sunflower cake & 2.50 & 1.30 & 0.00 & 1.70 & 1.50 & 2.1 .0 & 0.00 & 0.00 & 0.00 \\
\hline L. Threonine & 0.06 & 0.06 & 0.03 & 0.05 & 0.00 & 0.45 & 0.00 & 0.00 & 0.00 \\
\hline Soya oil & 0.00 & 0.00 & 0.00 & 0.00 & 1.60 & 3.00 & 0.00 & 1.30 & 2.40 \\
\hline Wheat bran & 0.00 & 0.00 & 2.10 & 0.00 & 0.00 & 0.00 & 0.00 & 0.00 & 0.00 \\
\hline Soya oil & 0.00 & 0.00 & 1.50 & 0.00 & 0.00 & 0.00 & 0.00 & 0.00 & 0.00 \\
\hline Maize meal, $8 \% \mathrm{CP}$ & 48.60 & 56.90 & 44.00 & 68.1 & 55.00 & 51.40 & 73.00 & 70.40 & 67.50 \\
\hline Fish meal 65\% CP & 1.20 & 4.90 & 5.00 & 4.6 & 4.60 & 5.00 & 0.10 & 1.00 & 2.00 \\
\hline DL Methionine & 0.30 & 0.29 & 0.79 & 0.19 & 0.16 & 0.11 & 0.15 & 0.15 & 0.07 \\
\hline Lysine HCL & 0.26 & 0.22 & 0.28 & 0.21 & 0.14 & 0.12 & 0.00 & 0.00 & 0.00 \\
\hline Monocacium phosphate & 0.50 & 0.30 & 0.30 & 0.2 & 0.30 & 0.30 & 0.16 & 0.15 & 0.07 \\
\hline Limestone & 0.88 & 0.43 & 0.40 & 0.65 & 0.50 & 0.27 & 0.74 & 0.55 & 0.36 \\
\hline Salt & 0.40 & 0.30 & 0.30 & 0.3 & 0.30 & 0.25 & 0.35 & 0.35 & 0.30 \\
\hline Broiler Premix ${ }^{123}$ & 0.30 & 0.30 & 0.30 & 0.3 & 0.30 & 0.30 & 0.30 & 0.30 & 0.30 \\
\hline Total & 100 & 100 & 100 & 100 & 100 & 100 & 100 & 100 & 100 \\
\hline \multicolumn{10}{|l|}{ Chemical composition } \\
\hline Crude protein $(\mathrm{g} / \mathrm{kg})$ & 226.00 & 226.13 & 225.28 & 199.90 & 199.74 & 200.12 & 175.00 & 174.94 & 174.93 \\
\hline ME (MJ/kg) & 12.50 & 12.46 & 12.39 & 13.09 & 13.07 & 13.08 & 13.20 & 13.21 & 13.18 \\
\hline $\mathrm{EE}(\mathrm{g} / \mathrm{kg})$ & 36.80 & 39.04 & 51.94 & 41.64 & 55.17 & 67.71 & 39.19 & 51.27 & 61.45 \\
\hline $\mathrm{CF}(\mathrm{g} / \mathrm{kg})$ & 41.50 & 40.15 & 49.98 & 34.38 & 39.88 & 46.84 & 31.90 & 37.88 & 43.86 \\
\hline $\mathrm{Ca}(\mathrm{g} / \mathrm{kg})$ & 9.98 & 9.52 & 9.88 & 9.22 & 5.59 & 5.60 & 4.93 & 8.63 & 8.74 \\
\hline$P(g / k g)$ & 7.08 & 7.10 & 7.04 & 6.53 & 6.61 & 6.58 & 6.00 & 6.02 & 6.08 \\
\hline Condensed tannins (\%) & 0.004 & 0.059 & 0.076 & 0.0036 & 0.056 & 0.083 & 0.0043 & 0.055 & 0.077 \\
\hline
\end{tabular}

Note. ${ }^{1}$ Composition: 9.9 u.i vitamin $\mathrm{A}, 1.95$ u.i vitamin $\mathrm{D}_{3}, 30$ u.i vitamin $\mathrm{E}, 2.9 \mathrm{~g}$ Vitamin $\mathrm{K} 3,2 \mathrm{~g}$ Vitamin B1, 7.5 g Vitamin B2, $30 \mathrm{~g}$ Vitamin PP Niacin, $12.1 \mathrm{~g}$ Vitamin B5, $3 \mathrm{~g}$ Vitamin B6, $1 \mathrm{~g}$ vitamin B9 Folic Acid, $150 \mathrm{mg}$ Vitamin B7/Biotin, $20 \mathrm{mg}$ Vitamin B12, $300 \mathrm{~g}$ Choline, $60 \mathrm{~g}$ Iron, $10 \mathrm{~g}$ Copper, $100 \mathrm{~g}$ Manganese, $100 \mathrm{~g}$ Zinc, $1 \mathrm{~g}$, Iodine, $0.5 \mathrm{~g}$ Cobalt, $300 \mathrm{mg}$ Selenium;

${ }^{2}$ Composition: 8 u.i vitamin A, 2 u.i vitamin D, 25 u.i vitamin E, 2 g Vitamin K3, 1.75 g Vitamin B1, 6 g Vitamin B2, $25 \mathrm{~g}$ Vitamin PP Niacin, $10 \mathrm{~g}$ Vitamin B5, $2 \mathrm{~g}$ Vitamin B6, $1 \mathrm{~g}$ vitamin B9 Folic Acid, $100 \mathrm{mg}$ Vitamin B7/Biotin, $15 \mathrm{mg}$ Vitamin B12, $250 \mathrm{~g}$ Choline, $50 \mathrm{~g}$ Iron, $8 \mathrm{~g}$ Copper, $80 \mathrm{~g}$ Manganese, $80 \mathrm{~g}$ Zinc, $1 \mathrm{~g}$, Iodine , 0.5 g Cobalt, $250 \mathrm{mg}$ Selenium;

${ }^{3}$ Composition: 6 u.i vitamin A, 1.5 u.i vitamin $\mathrm{D}_{3}, 20$ u.i vitamin E, $1.5 \mathrm{~g}$ Vitamin K3, $1.5 \mathrm{~g}$ Vitamin B1, $5 \mathrm{~g}$ Vitamin B2, $25 \mathrm{~g}$ Vitamin PP Niacin, $8 \mathrm{~g}$ Vitamin B5, $1.5 \mathrm{~g}$ Vitamin B6, $0.6 \mathrm{~g}$ vitamin B9 Folic Acid, $80 \mathrm{mg}$ Vitamin B7/Biotin, $15 \mathrm{mg}$ Vitamin B12, $200 \mathrm{~g}$ Choline, $40 \mathrm{~g}$ Iron, $6 \mathrm{~g}$ Copper, $80 \mathrm{~g}$ Manganese, $60 \mathrm{~g}$ Zinc, $1 \mathrm{~g}$, Iodine, $0.25 \mathrm{~g}$ Cobalt, $200 \mathrm{mg}$ Selenium.

At week 2, 4 and 6, two chicks from each replicate were slaughtered and dressed. Dressed weight was measured. The duodenum, jejunum, and colon were removed and weighed. Intestinal length was measured. The weight and lengths of organs were expressed as proportions of hot dressed weight. Of each intestinal segment $1 \mathrm{~cm}$ was cut, intestinal contents were flushed with distilled water and fixed in $10 \%$ saline formalin. The fixed fragments were stained on slides using the procedure described by W. Bacha and L. M. Bacha (2000). Using a Leitz MD5 light microscope fitted with an eye piece graticle, the functional capacity of the duodenum, jejenum and colon was assessed as follows:

At $\mathrm{x} 4$ magnification, 10 observations were recorded for each of the following duodenum and jejunum morphometric parameters: intestinal wall thickness, epithelial thickness, villus height and villus width. 
Measurements for each parameter were averaged into one value per bird. On the colon, ten points along the intestines were chosen to measure intestinal wall thickness, mucosal layer thickness, semi-luna fold height and width and haustra coli width at $\mathrm{x} 4$ magnification and mean values calculated. To determine the effect of diet on intestinal morphology and dressed weight, ANOVA was computed using the General Linear Model Procedure of SAS (2000) version 9.3. Comparison of means was done using Tukey's test.

\section{Results}

Inclusion of leaf meal resulted in an increase in thickness of the duodenum wall $(P<0.05)$. The $5 \%$ leaf meal fed birds exhibited the thickest duodenum wall which was not different from the $10 \%$ fed birds (Table 3 ). Duodenum villi height increased significantly with increasing leaf meal levels $(P<0.05)$ (Table 3). Birds fed the control diet recorded the shortest villi height while those fed the $10 \%$ diet exhibited the longest villus. The average width of duodenum villus was the same across treatments $(P>0.05)$. Duodenum epithelium thickness increased significantly with addition of leaf meal in the $\operatorname{diet}(P<0.05)$ (Table 3$)$.

Table 3. Effect of increasing levels of $A$. angustissima leaf meal of duodenal parameters

\begin{tabular}{lllll}
\hline Duodenum Parameter & Control & $\mathbf{5 \%} \mathbf{A . A}$ & $\mathbf{1 0 \%} \mathbf{A . A}$ & SE \\
\hline Proportionate weight (\%) & 1.29 & 1.41 & 1.39 & 0.048 \\
Proportionate length (\%) & $40.13^{\mathrm{a}}$ & $43.26^{\mathrm{a}}$ & $48.60^{\mathrm{b}}$ & 1.748 \\
Wall thickness (mm) & $0.21^{\mathrm{a}}$ & $0.34^{\mathrm{b}}$ & $0.33^{\mathrm{b}}$ & 0.011 \\
Villi height(mm) & $0.88^{\mathrm{a}}$ & $0.98^{\mathrm{ab}}$ & $1.11^{\mathrm{b}}$ & 0.036 \\
Villi width (mm) & 0.11 & 0.11 & 0.11 & 0.003 \\
Epithelial thickness(mm) & $1.17^{\mathrm{a}}$ & $1.22^{\mathrm{ab}}$ & $1.32^{\mathrm{b}}$ & 0.040 \\
\hline
\end{tabular}

Note. ${ }^{\text {abc }}$ Within a row, means without a common superscript differ $(P<0.05)$.

Treatment did not affect the proportional weight and length of the jejunum, jejunum villi height and villi width $(P>0.05)$ but affected jejunum wall thickness $(P<0.05)$ (Table 4). The jejunum wall thickness decreased with increasing levels of leaf meal in the diet $(P<0.05)$ (Table 4). The thickest wall was from the control fed birds while the $10 \%$ leaf meal fed birds exhibited the thinnest jejunum wall.

Table 4. Effect of increasing levels of $A$. angustissima on jejenum parameters

\begin{tabular}{lllll}
\hline Jejunum Parameter & Control & $\mathbf{5 \%}$ A.A & $\mathbf{1 0 \%}$ A.A & SE \\
\hline Proportionate weight (\%) & 3.040 & 3.071 & 4.462 & 0.6433 \\
Proportionate length (\%) & 88.100 & 86.470 & 93.060 & 3.1391 \\
Wall thickness (mm) & $0.340^{\mathrm{a}}$ & $0.301^{\mathrm{b}}$ & $0.259^{\mathrm{b}}$ & 0.0140 \\
Villi height (mm) & 0.550 & 0.572 & 0.597 & 0.0203 \\
Villi Width (mm) & 0.110 & 0.111 & 0.102 & 0.0032 \\
Epithelium thickness (mm) & 0.800 & 0.823 & 0.846 & 0.1975 \\
\hline
\end{tabular}

Note. ${ }^{\text {abc }}$ Within a row, means without a common superscript differ $(P<0.05)$, A.A $=$ A. angustissima.

Weight of the colon increased by $51.51 \%$ and $36 \%$ on addition of $5 \%$ and $10 \%$ leaf meal, respectively $(P<0.05)$ (Table 5). The intestinal wall and mucosal thickness of the colon increased by 52.80 and $20.31 \%$ on inclusion of the 5 and $10 \%$ leaf meal, respectively $(P<0.05)$ (Table 5$)$. The increases at $10 \%$ inclusion of the leaf meal were only numerical and not different from the control fed birds $(P>0.05)$. A significant decline in sub-mucosal fold height and haustra coli width was noted at 10\% leaf meal inclusion $(P<0.05)$ (Table 5). 
Table 5. The physiological response of the colons to graded levels of A. angustissima leaf meal

\begin{tabular}{lllll}
\hline Colon Parameter & Control & $\mathbf{5 \%} \mathbf{A . A}$ & $\mathbf{1 0 \%} \mathbf{A . A}$ & $\mathbf{S E}$ \\
\hline Proportionate weight (\%) & $0.330^{\mathrm{a}}$ & $0.500^{\mathrm{b}}$ & $0.450^{\mathrm{b}}$ & 0.0324 \\
Proportionate length (\%) & 11.670 & 12.530 & 12.930 & 0.6281 \\
Wall thickness (mm) & $0.536^{\mathrm{a}}$ & $0.819^{\mathrm{b}}$ & $0.571^{\mathrm{a}}$ & 0.0310 \\
Mucosal layer thickness (mm) & $0.396^{\mathrm{a}}$ & $0.599^{\mathrm{b}}$ & $0.475^{\mathrm{a}}$ & 0.0274 \\
Sub-mucosal fold width (mm) & 0.174 & 0.207 & 0.159 & 0.0180 \\
Sub-mucosal fold height (mm) & $0.479^{\mathrm{a}}$ & $0.405^{\mathrm{ab}}$ & $0.336^{\mathrm{b}}$ & 0.0303 \\
Haustra coli width (mm) & $1.094^{\mathrm{a}}$ & $0.871^{\mathrm{ab}}$ & $0.789^{\mathrm{b}}$ & 0.0891 \\
\hline
\end{tabular}

Note. ${ }^{\text {abc }}$ Within a row, means without a common superscript differ $(P<0.05)$.

The effect of treatment on dressed weight depended on the age of the bird $(P<0.05)$ (Figure 1). No differences among treatments were noted at two weeks of age $(P>0.05)$. At four and six weeks of age, dressed weights from the control and $5 \%$ fed broilers outperformed the $10 \%$ fed birds.

$$
\text { ...... Control - } 5 \% \text { A. angustissima }-10 \% \text { A. angustissima }
$$

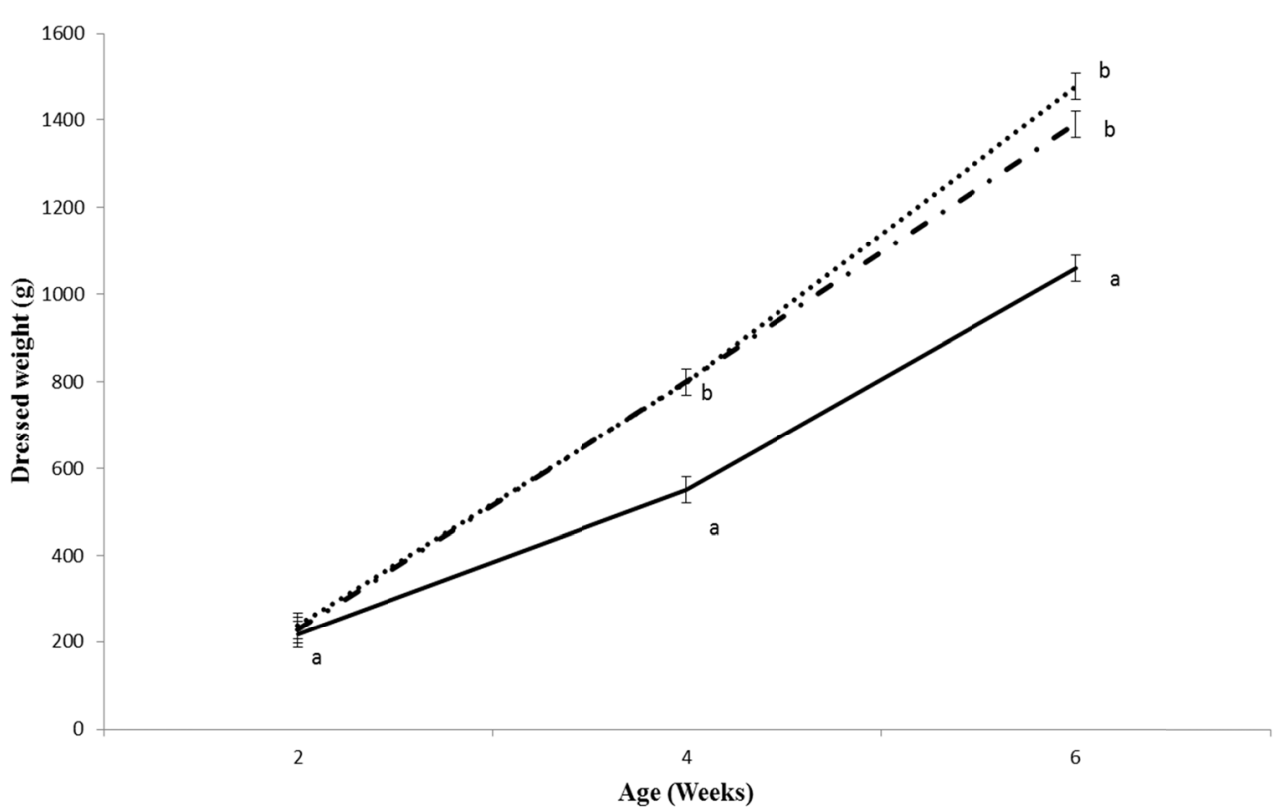

Figure 1. Effect of increasing levels of A. angustissima leaf meal on dressed weight at different ages of growth

\section{Discussion}

The morphological changes in the duodenum and colon indicate increased digestive and absorptive capacity of the intestines. The increase in the length and weight of the intestinal segments in the current study is a physical adaptation to presence of the A. angustissima leaf meal. This represent enhanced development of the intestinal segments (Jiang et al., 2012) and thus increased capacity and volume, possibly as a result of greater quantity than quality of feed (Chiou, Lu, Hsu, \& Yu, 1996). The increase in intestinal volume was therefore a physiological adaptation to take care of increased feed volumes associated with the leaf meal based formulations. While high fiber content in the leaf meal based formulations imply increased feed volume, it is also associated with a decrease in nutrients density (Shafey, Almufarij, \& Albatshan, 2013) possibly explaining the compromised growth from the $10 \%$ fed broilers even after the increase in intestinal capacity.

Increase in the length of the duodenum could also be a result of an increase in gastro-duodenal refluxes as triggered by the high fiber content in leaf meal based diets (Mateos, Jimenez-Monero, Serrano, \& Lazaro, 2012; 
Martens et al. (2012). In general, increase in fiber component of the diet increases digesta reflux between the gizzard and the duodenum (Sacranie, Svihus, Denstadli, Moen, Iji, \& Choct, 2012). Such a response can be explained by the need to prolong the feed to both chemical and mechanical digestion for increased nutrient release. The increases in the colon could be a response to increased bulkiness of the feed due to dietary fiber (Chiou et al., 1996).

Although the adaptation by the duodenum and the colon could represent an increase in capacity of the organs, at $10 \%$ inclusion of the leaf meal, growth is negatively affected during the last two phases of feeding. Intestinal adaptation to $10 \%$ leaf meal inclusion could support weight gain during the starter phase as noted by the none significant effect on dressed weight. During the grower and finisher phases of feeding, the dressed weight indicated failure of intestinal adaptation to support weight gain at $10 \%$ leaf meal inclusion. This due to diversion of nutrients from growth of edible carcass (Iyayi, Ogunsola, \& Ijaya, 2005) growth of the gastrointestinal organs. An increase in intestinal capacity is also associated with increasing energy and amino acid requirements for maintenance by the animal (Johnston \& Noll, 2003). Thus, the increase in the intestinal weights and length at $10 \%$ inclusion of the leaf meal do not translate to good carcass weights. This concurs with findings by Ncube, Hamudikuwanda, and Saidi (2012c) who concluded that continued use of A. angustissima leaf meal diet at $10 \%$ compromised growth of birds. Shafey et al. (2013) also noted an increase in intestinal capacity after feeding olive leaves and this was also associated with a decline in growth performance of birds as olive leaves increased in broiler diets.

Thickening of the duodenum and colon muscle layer with increasing leaf meal could also be explained by the intense work load or effort by the intestines in propelling digesta along the digestive tract as dietary crude fiber in diets increased. Any thickening of the muscle layer along the digestive tract represents stronger movements during digesta transportation. It is also indicative of a highly activated digestion and absorption function (Al-Tememy, Al-Jaff, Al-Mashhadani, \& Hamodi, 2011). Unlike in the duodenum and colon, the jejunum muscle layer decreased in thickness with addition of the leaf meal. It is not clear why the response differed in the jejunum because according to Block, Vahl de Lange, Van de Braak, Henke, and Hessing (2002), when birds are fed diets with poorly enzymatically digestible materials, intestinal walls should get thicker. The different responses could be related to the roles of the intestinal segments in digestion. The duodenum muscle is also involved in the grinding cycle together with the gizzard (Svihus, 2014), and this could easily explain the thickening of the muscle. Presence of fiber in poultry feed increases the intensity of gastro-duodenum refluxes (Mateos et al., 2012). The duodenum area is also the main site for mixing digesta and secretions while the colon is responsible for transportation of digesta to the cloacae (McDonald et al., 2010), thus thickening of the walls of these two intestinal segments could be representative of their functions. While the increase in crude fiber delays passage of feed from the gizzard for further grinding, it is also said to accelerate the passage of feed through the intestines. The involvement of the duodenum in the grinding cycle could better explain its thickening while the decrease in intestinal thickness in the jejenum could possibly be explained by the faster rates of digesta movement along the segment.

Because the colon's main motility is through haustra contractions (Sherwood, 2012), significant decreases in haustra width with increasing levels of leaf meal represent the shortening of distance between any two semi-luna folds, thus more folds within a length. Haustra are produced by circular and longitudinal muscle contractions that narrow the lumen and shorten the colon (Alpers \& Yamanda, 2009). More folds in the colon would result in increases in the propulsive force, increasing rate of bolus passage along the colon. The increasing fiber content in leaf meal based diets is likely to have stimulated colon motility (Staniforth, Baird, Fowler, \& Lister, 1991; Brownlee, Dettmar, Strugala, \& Pearson, 2006; Zeng, Lazarova, \& Bordonaro, 2014) resulting in increases in the number of colon folds. Such segmental contractions result in increased water absorption and electrolyte exchange (Maykel \& Opelka, 2004) and possibly reduced contact time between digesta and intestinal lumen. This is important as it reduces colon mucosal exposure to potential damaging agents of either endogenous or exogenous origin (Brownlee et al., 2006) while allowing the colon to absorb as much water as is possible.

The increase in villi height could have been triggered by the inefficiencies associated with the presence of leaf meal in the diet. Since intestinal tissue possesses the ability to adapt to the nutritional environmental (Mitchell \& Moreto, 2006), the increase in villi height could have been an attempt to increase the digestive and absorptive capacity as the inefficiencies associated with presence of the leaf meal increased. Increased villi height suggests an increased surface area for satisfactory digestive enzyme action and higher nutrient absorption (Dibner \& Richards, 2004; Watson, 2009; Varastegani \& Dahlan, 2014; Shomali et al., 2015). Increase in total epithelial thickness of the intestines is indicative of suboptimal digestion due to the presence of the leaf meal. According to Bedford (2006), the general perception is that increase in size of the gastro-intestinal tract components represents 
suboptimal digestion, thus the need for the physiological adaptations. However, such adaptations to match digestion and absorption in normal diets may actually cost the broilers more energy than the benefits. As a result growth may be affected and linked to this is a decline in feed efficiency (Bedford, 2006). This is attributed to the fact that nutrients will first be directed towards maintenance of the chicken's current biological state (Dibner \& Richards, 2004; Watson, 2009, Shaw, Gohil, \& Basson, 2012) and only after that will any additional nutrients be directed towards growth. Thus, at $10 \%$ inclusion of the leaf meal, although the digestive and absorptive capacities of the intestines increased, beyond two weeks of age, carcass weights were negatively affected. The increase in functional capacities during the starter period for birds on the leaf meal based diets did not affect weight gain. However during the grower and finisher phases of growth and possibly due to greater demand for nutrients as the birds grew, only those broiler on the 5\% leaf meal diet gained weight as well as the control. Failure of broilers on the $10 \%$ leaf meal to attain expected weights could be associated with increase in maintenance requirements of the gastrointestinal tract. This implies that the gastrointestinal maintenance demands for broiler on the $10 \%$ leaf meal diets may have cost the broilers more energy than the benefit from the adaptation during the grower and finisher phases of growth.

\section{Conclusion}

Intestinal adaptations of the leaf meal based diets supported expected carcass weights up to two weeks of age. Beyond two weeks of feeding, physiological adaptations from the $10 \%$ leaf meal fed broilers failed to support growth to the expected carcass weights. The results from this study imply that A. angustissima leaf meal could be included in broiler diets upto $10 \%$ only in starter diets as the intestines can make physiological adjustments without compromising carcass weights. Beyond two weeks of age, the optimum inclusion levels of $A$. angustissima in broiler diets is $5 \%$ since at $10 \%$ inclusion, intestinal adjustments failed to support optimum growth.

\section{References}

Alpers, D., \& Yamada, T. (2009). Textbook of Gastroenterology (p. 2907). Chichester, West Sussex: Wiley-Blackwell.

Al-Tememy, H. S. A., Al-Jaff, F. K., Al-Mashhadani, E. H., \& Hamodi, S. J. (2011). Histological effect of inclusion different levels of coriander oil in broiler diet on small intestine. Diyala Agricultural Sciences Journal, 3(2), 1-11.

Association of Official Analytical Chemists (AOAC). (1990). Official Methods of Analysis (15th ed.). Washington DC, USA.

Bacha, W. J. Jr, \& Bacha, L. M. (2000). Color Atlas of veterinary Histology (2nd ed.). Lippincott Williams and Wilkins, Philadelphia, USA.

Bedford, M. R. (2006). Effect of non starch polysaccharide on avian gastrointistanal function. In G. C. Perry (Ed.), Avian Gut Function in Health and Disease (p. 30). Cambridge, MA, USA: CABI Publishing. https://doi.org/ 10.1079/9781845931803.0159

Block, M. C., Vahl de Lange, H. A. L., Van de Braak, A. E., Henke, G., \& Hessing, M. (2002). Nutrition and health of the gastrointestinal tract (p. 16). Wageningen Academic Publishers, The Netherlands. https://doi.org/10.3920/978-90-8686-505-5

Brownlee, I. A., Dettmar, P. W., Strugala, V., \& Pearson, J. P. (2006). The interaction of dietary fibers with the colon. Current Nutrition and Food Sciences, 2, 243-264. https://doi.org/10.2174/157340106778017896

Casartelli, E. M., R. S., Filardi, O. M., Junqueira, A. C., Laurentiz, V. A., \& Duarte, K. (2006). Sunflower meal in commercial layer diets formulated on total and digestible amino acids basis. Brazilian Journal of Poultry Science, 8(3), 167-171. https://doi.org/10.1590/s1516-635×2006000300005

Chiou, P. W. S., Lu, T. W., Hsu, J. C., \& Yu, B. (1996). Effect of different sources of fiber on the intestinal morphology of domestic geese. Asian-Australasian Journal of Animal Science, 9(5), 539-550. https://doi.org/10.5713/ajas.1996.539

Dibner, J. J., \& Richards, J. D. (2004). The digestive system: Challenges and opportunities. Journal of Applied Poultry Research, 13(1), 84-93. https://doi.org/10.1093/japr/13.1.86

Dzowela, B. H. (1994). Acacia angustissima a central American tree that's going places. Agroforestry Today, 6, 13-14. 
Gusha, J., Ngongoni, N. T., \& Halimani, T. E. (2013). Nutritional composition and effective degradability of four forage trees grown for protein supplementation. Online Journal of Animal Feed Research, 3(4), 170-175.

Haoyu, L., Ivarsson, E., Lundh, T., \& Lindberg, J. E. (2013). Chicory (Cichorium intybus L.) and cereals differently affect gut development in broiler chickens and young pigs. Journal of Animal Science and Biotechnology, 4(1), 1-12.

Iyayi, E. A., Ogunsola, O., \& Ijaya, R. (2005). Effect of three sources of fiber and period of feeding on the performance, carcass measures, organs relative weight and meat quality in broilers. International Journal of Poultry Science, 4(9), 695-700. https://doi.org/10.3923/ijps.2005.695.700

Ja'afar-Furo, M. R., \& Gabdo, B. H. (2010). Identifying Major factors of poultry production as sustainable enterprise among farmers using improved methods in rural Nigeria. International Journal of Poultry Science, 9(5), 459-463. https://doi.org/10.3923/ijps.2010.459.463

Jiang, J. F., Sang, X. M., Huang, X., Zhou, W. D., Wu, J. L., Zhu, H. C., \& Jiang, Y. Q. (2012). Effects of Alfalfa meal on growth performance and gastrointestinal tract development of growing ducks. Asian-Australasian Journal of Animal Science, 25(10), 1445-14450. https://doi.org/10.5713/ajas.2012.12190

Johnston, L. J., \& Noll, S. L. (2003). Feeding by products high in concentration of fibre to nonruminants. Paper presented at the Third National Symposium on Alternative Feeds for Livestock and Poultry held in Kansas City, Mo. Retrieved from https://pdfs.semanticscholar.org/bdf7/8cb1a5649979d8612435937f8d8e45d1d3f c.pdf

Koutsos, E. A., \& Arias, V. (2006). Intestinal ecology: Interaction among the gastrointestinal tract, nutrition and the microflora. Journal of Applied Poultry Research, 15, 161-173. https://doi.org/10.1093/japr/15.1.161

Martens, S. D., Tiemann, T. T., Bendelle, J., Peters, M., \& Lascano, C. E. (2012). Alternative plant protein sources for pigs and chickens in the tropics: Nutritional value and constraints: A review paper. Journal of Agriculture and Rural Development in Tropics and Subtropics, 113(12), 101-123. Retrieved from http://www.jarts.info/index.php/jarts/article/view/2012092441794/191

Mateos, G. G., Jimenez-Monero, E., Serrano, M. P., \& Lazaro, R. P. (2012). Poultry responses to high levels of dietary fiber sources varying in physical and chemical characteristics. Journal of Applied Poultry Science, 21(1), 156-174. https://doi.org/10.3382/japr.2011-00477

Maykel, J. A., \& Opelka, F. G. (2004). Colon Diverticulosis and Diverticular Hemorrhage. Clinics in Colon and Rectal Surgery, 17(3), 195-204. https://doi.org/10.1055/s-2004-832702

McDonald, P. R., Edwards, A., Greenhalgh, J. F. D., Morgan, C. A., Sinclair, L. A., \& Wilkinson, R. G. (2010). Animal Nutrition (7th ed., p. 156). Prentice Hall. U.K.

McSweeney, C. S., Gough, J., Conlan, L. L., Hegarty, M. P., Palmer, B., \& Krause, D. O. (2005). Nutritive value assessment of the tropical shrub legume Acacia angustissima: anti-nutritional compounds and in vitro digestibility. Animal Feed Science and Technology, 12(1-2), 175-190. https://doi.org/10.1016/j.anifeedsci. 2005.02.017

Mitchell, M. A., \& Moreto, M. (2006). Absorptive function of small intestine: Adaptations meeting demand in Avian Gut function in health an disease. In G. C. Perry (Ed.), Avian Gut Function in Health and Disease (p. 41). Cambridge, MA, USA: CABI Publishing. https://doi.org/10.1079/9781845931803.0043

Moreki, J. C. (2011). Challenges in small-scale broiler production in Botswana. Journal of Agricultural Technology, 7(6), 1579-1587.

Mukandiwa, L., Mugabe, P. H., Halimani, T. E., \& Hamudikuwanda, H. (2010). A note on the effect of supplementing rangeland grazing with Acacia angustissima mixed with pearl millet on growth performance of goats in a smallholder farming area in Zimbabwe. Livestock Research for Rural Development, 22(9). Retrieved from http://www.lrrd.org/lrrd22/1/muka22009.htm

Mutayoba, S. K., Dierenfed, E., Mercedes, V. A., Frances, Y., \& Knight, C. D. (2011). Determination of chemical and anti-nutritive components for Tanzanian locally available poultry feed ingredients. International Journal of Poultry Science, 10(5), 350-357. https://doi.org/10.3923/ijps.2011.350.357

National Research Council (NRC). (1994). The nutrient requirements of farm animals (9th ed.). Academy of Science, Washington D.C. USA. 
Ncube, S., Hamudikuwanda, H., \& Banda, P. T. (2012a). The Potential of Acacia angustissima Leaf Meal as a Supplementary Feed Source in Broiler Finisher Diets. International Journal of Poultry Science, 11(1), 55-60. https://doi.org/10.3923/ijps.2012.55.60

Ncube, S., Hamudikuwanda, H., \& Saidi, P. T. (2012b). Carcass yield and characteristics in broilers fed Acacia angustissima leaf meal-based diets. Journal of Zimbabwe Studies: Science, Technology and Health, 1(1), 72-78.

Ncube, S., Hamudikuwanda, H., \& Saidi, P. T. (2012c). Voluntary feed intake and growth of broilers on Acacia angustissima leaf meal based starter and finisher diets. Livestock Research for Rural Development, 24(128). Retrieved from http://www.lrrd.org/lrrd24/8/ncub24128.htm

Ncube, S., Saidi, P. T., \& Halimani, T. E. (2015). Effect of stage of growth and processing methods on the nutritional content of Acacia angustissima leaf meal harvested for broiler feeding. Livestock Research for Rural Development, 27(89). Retrieved from http://www.lrrd.org/lrrd27/5/ncub27089.html

Ntuli, V., \& Oladele, O. I. (2013). Analysis of constraints faced by small scale broiler farmers in Capricon District in Limpopo province. Life Sciences Journal, 10(1), 3990-3996. Retrieved from http://www.lifesciencesite.com/lsj/life1001/366_17038life1001_2990_2996.pdf

Odenyo, A. A., Osuji, P. O., Reed, J. D., Smith, A. H., Mackie, R. I., McSweeney, C. S., \& Hanson, J. (2003). Acacia angustissima: Its antinutrients, constituents, toxicity and possible mechanism to alleviate the tocixity-A short review. Agroforestry Systems, 59(2), 141-147. https://doi.org/10.1023/A:1026360912944

Oladokun, V. O., \& Jonhson, A. (2012). Feed formulation problem in Nigerian Poultry farms: A mathematical programming approach. American Journal of Scientific and industrial Research, 3(1), 14-20. https://doi.org/10.5251/ajsir.2012.3.1.14.20

Porter, L. J., Hrstich, L. N., \& Chan, B. G. (1986). The conversion of procyanidins and prodelphinidins to cyaniding and delphinidin. Phytochemistry, 25(1), 223-230. https://doi.org/10.1016/S0031-9422(00)94533-3

Preece, D., \& Brook, R. (1999). Acacia angustissima-a promising species for agroforestry? FACT Sheet 99-01. A quick guide to multipurpose trees from around the world. FACT Net Winrock International Arkansas. Retrieved from http://factnet.winrock.org/fnrm/factnet/factpub/FACTSH/angustissima.htm

Reed, J. D., Girmal, G. M., Robinson, C. J., Honson, J., Odenyo, A., \& Treichel, P. M. (2001). Acetyldiaminobutonoic acid, a potential lathyrogenic amino acid in leaves of Acacia angustissima. Journal of the Science of Food and Agriculture, 81(15), 1481-1486. https://doi.org/10.1002/jsfa.960

Roberts, S. T., Wilson, J., Guthrie, A., Cookson, K., Vancraeynest, D., Schaeffer, J., Moody, R., \& Clark, S. (2005). New issues and science in broiler chicken intestinal health: Emerging technology and alternate interventions. Poultry Science, 24(2), 257-266.

Rubanza, C. D. K., Shem, M. N., Bakengesa, S. S., Ichinohe, T., \& Fujihara, T. (2007). The content of protein, fiber and minerals of leaves of selected Acacia species indigenous to north-western Tanzania. Arch. Tierernähr, 61(2), 151-156.

Sacranie, A., Svihus, B., Denstadli, V., Moen, B., Iji, P. A., \& Choct, M. (2012). The effect of insoluble fiber and intermittent feeding on gizzard development, gut motility and perfomance of broiler chickens. Poultry Science, 91(3), 693-700. https://doi.org/10.3382/ps.2011-01790

Sambo, E., Bettridge, J., Dessie, T., Amone, A., Hable, T., Wigley, P., \& Chrstley, R. M. (2015). Participatory evaluation of Chicken health and production constraints in Ethiopia. Preventative Veterinary Medicine, 118(1), 117-127. https://doi.org/10.1016/j.prevetmed.2014.10.014

Shafey, T. M., Almufarij, S. I., \& Albatshan, H. A. (2013). Effect of feeding olive leaves on perfomance, intestinal and carcass characteristics of broiler chickens. International Journal of Agriculture and Biology, 13(3), 585-589. Retrieved from https://www.fspublishers.org/published_papers/662_..pdf

Shaikh, A. S., \& Zala, Y. C. (2011). Production Performance and Economic Appraisal of Broiler Farms in Anand District of Gujarat. Agriculture Economics Research Review, 24(2), 317-323. Retrieved from http://ageconsearch.umn.edu/bitstream/119385/2/15-AS-Shaikh.pdf

Shaw, D., Gohil, K., \& Basson, M. (2012). Intestinal mucosal atrophy and adaptation. World Journal of Gastroenterology, 18(44), 6357-6375. https://doi.org/10.3748/wjg.v18.i44.6357 
Sheffield, J., \& Wood, E. F. (2010). Global trends and variability in soil moisture and drought characteristics 1950-2000 from observation driven simulations of the terrestrial hydrologic cycle. Journal of Climate, 21, 432-458. https://doi.org/10.1175/2007JCLI1822.1

Sherwood, L. (2012). Fundamentals of Human Physiology (4th ed., p. 436). Brooks/Cole, Belmont, USA.

Staniforth, D. H., Baird, I. M., Fowler, J., \& Lister, R. E. (1991). The effects of dietary fiber on upper and lower gastor-intestinal transit times and feacal bulking. Journal of International Medical Research, 19, 228-233.

Statistical Analysis System (SAS). (2000). User's Guide, Statistics. SAS Institute Inc. Cary, North Cariolina, USA.

Svihus, B. (2014). Function of the digestive system. Journal of Applied Poultry Research, 23, 1-9. https://doi.org/10.3382/japr.2014-00937

Varastegani, A., \& Dahlan, I. (2014). Influence of dietary fiber levels on feed utilization and growth performance in Poultry. Journal of Animal Production Advances, 4(6), 422-429.

Watson, R. W. (2009). Handbook of Nutrition in the Aged (4th ed.). Taylor and Francis Group, USA.

Zeng, H., Lazarova, D. L., \& Bordonaro, M. (2014). Mechanisms linking dietary fiber, gut microbiota and colon cancer prevention. World Journal of Gastrointestinal Oncology, 6(2), 41-51. https://doi.org/10.4251/ wjgo.v6.i2.41

\section{Copyrights}

Copyright for this article is retained by the author(s), with first publication rights granted to the journal.

This is an open-access article distributed under the terms and conditions of the Creative Commons Attribution license (http://creativecommons.org/licenses/by/4.0/). 